\title{
Bendamustine in Metastatic Breast Cancer: An Old Drug in New Design
}

\author{
Cristina Pirvulescu Gunter von Minckwitz Sibylle Loibl \\ German Breast Group, GBG Forschungs GmbH, Neu-Isenburg, Germany
}

\section{Key Words}

Bendamustine · First-line chemotherapy ·

Metastatic breast cancer

\begin{abstract}
The goal of treatment for patients with advanced breast cancer is to prolong survival, control symptoms, and reduce disease-related complications. Despite the introduction of many cytotoxic agents during the past decade, only modest improvement in survival in metastatic breast cancer has been achieved. In order to improve this situation, new cytotoxic drugs as well as molecule-targeted agents are now under investigation. Bendamustine is a bifunctional alkylating agent with cytotoxic activity against several types of solid tumors. In the search for new anthracycline-free combinations, taxanes and alkylating agents might be worth investigating, in order to reduce cardiac toxicity. In this article, we reviewed the latest information regarding antitumor activity, toxicity, pharmacokinetics, and clinical application of bendamustine as a cytotoxic agent in metastatic breast cancer.
\end{abstract}

\section{Introduction}

Metastatic breast cancer (MBC) is incurable; the median time of survival is $2-3$ years [1]. Only a limited number of patients

\author{
Schlüsselwörter \\ Bendamustin · First-line Chemotherapie · \\ Metastasiertes Mammakarzinom
}

\section{Zusammenfassung}

Die Verbesserung des Überlebens ohne Einschränkung der Lebensqualität, das Management der klinischen Beschwerden und die Verminderung der krankheitsbedingten Komplikationen stehen im Fokus der Therapieplanung bei Patientinnen mit metastasiertem Mammakarzinom. Trotz der Einführung neuerer zytotoxischer Medikamente in den letzten Jahrzehnten ist die Verlängerung des Überlebens im metastasierten Stadium bisher nur marginal verbessert worden. Daher werden neue chemotherapeutische, endokrine, vor allem aber zielgerichtete Ansätze im Rahmen zurzeit laufender klinischer Studien untersucht, um die Prognose für diese Zielgruppe weiter zu verbessern. Bendamustin ist ein bifunktionelles alkylierendes Zytostatikum, das neben hämatologischen Erkrankungen auch bei verschiedenen soliden Tumoren Einsatz findet. Der Einsatz von Anthrazyklin-freien Therapiekombinationen mit geringen kardiotoxischen Eigenschaften, wie die Taxane und Alkylantien, soll in weiteren Untersuchungen etabliert werden. In dieser Übersichtsarbeit wurden die wesentlichen aktuelleren Daten bezüglich der antitumoralen Wirkungsmechanismen, des Toxizitätsprofils und der Effektivität von Bendamustin bei Patientinnen mit metastasiertem Mammakarzinom zusammengetragen.

survives more than 10 years after the diagnosis of metastases. Nevertheless, an analysis from Giordano and colleagues [2] suggests that the survival of women with recurrent breast cancer has been overall improved over the past three decades.

\section{KARGER}

Fax +497614520714

Information@Karger.de

www.karger.com (c) 2008 S. Karger GmbH, Freiburg

Accessible online at:

www.karger.com/brc 


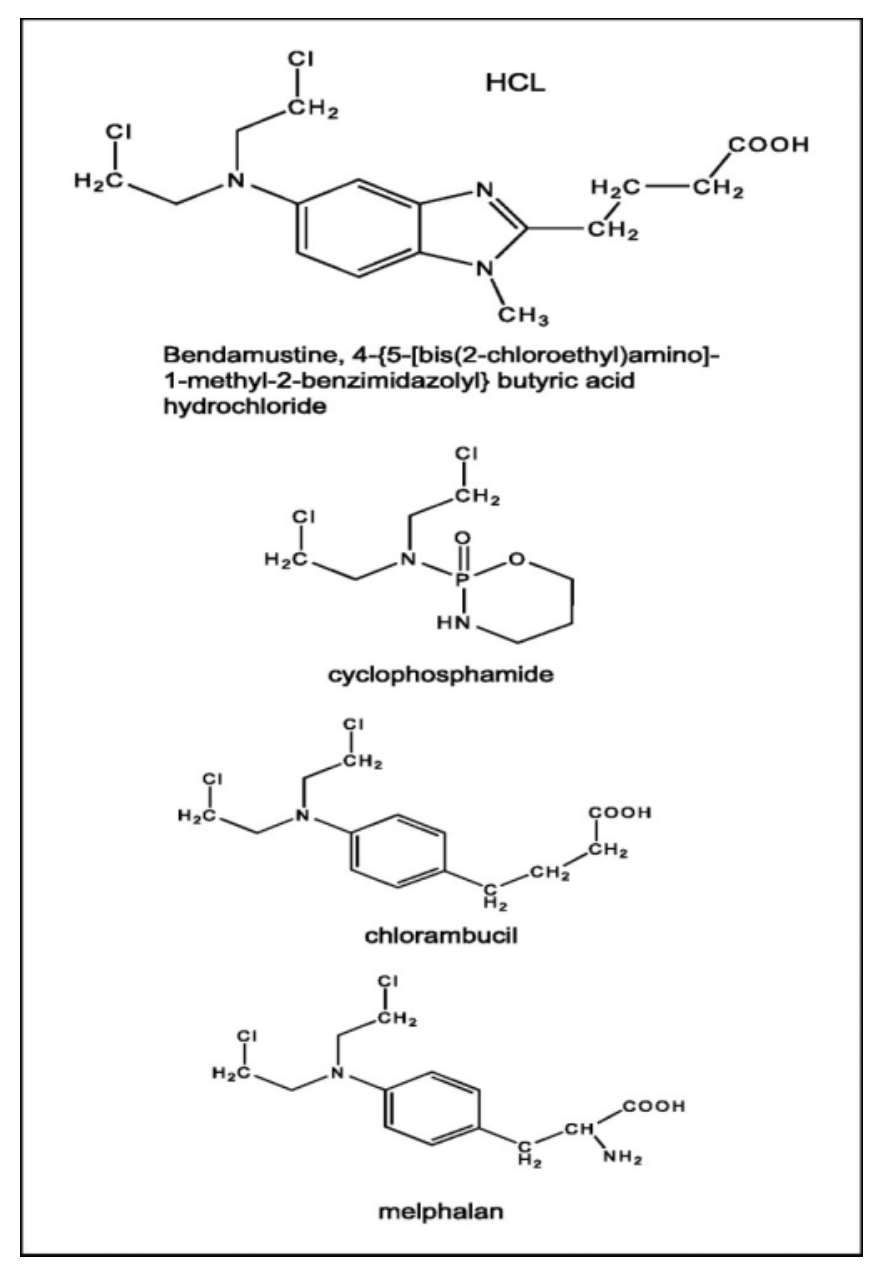

Fig. 1. Chemical structure of bendamustine.

Therefore, the main aim of the treatment is not to cure but palliation, which can be achieved by chemotherapy, endocrine treatment, bisphosphonates, surgery, radiotherapy, and palliative treatment. Since the mid 1990s, a number of new agents have been introduced to the treatment of breast cancer, such as the taxanes, vinca alkaloids, oral formulations of known drugs, and antibodies.

\section{Bendamustine: Pharmacological Profile}

Bendamustine hydrochloride (fig. 1) is the active ingredient of Ribomustin ${ }^{\circledR}$ (Mundipharma GmbH, Limburg, Germany). It was originally synthesized in 1963 in Jena, Germany, with the intention of producing an antineoplastic agent with low toxicity and both alkylating and antimetabolic properties, and was first used in multiple myeloma. Bendamustine has 3 active moieties: (i) an alkylating group, in common with the nitrogen mustard family, (ii) a benzimidazole ring, which may act as a purine analogue, and (iii) a butyric acid side chain [3]. However, it has been shown that, at high concentrations, it primarily
Table 1. Properties of bendamustine

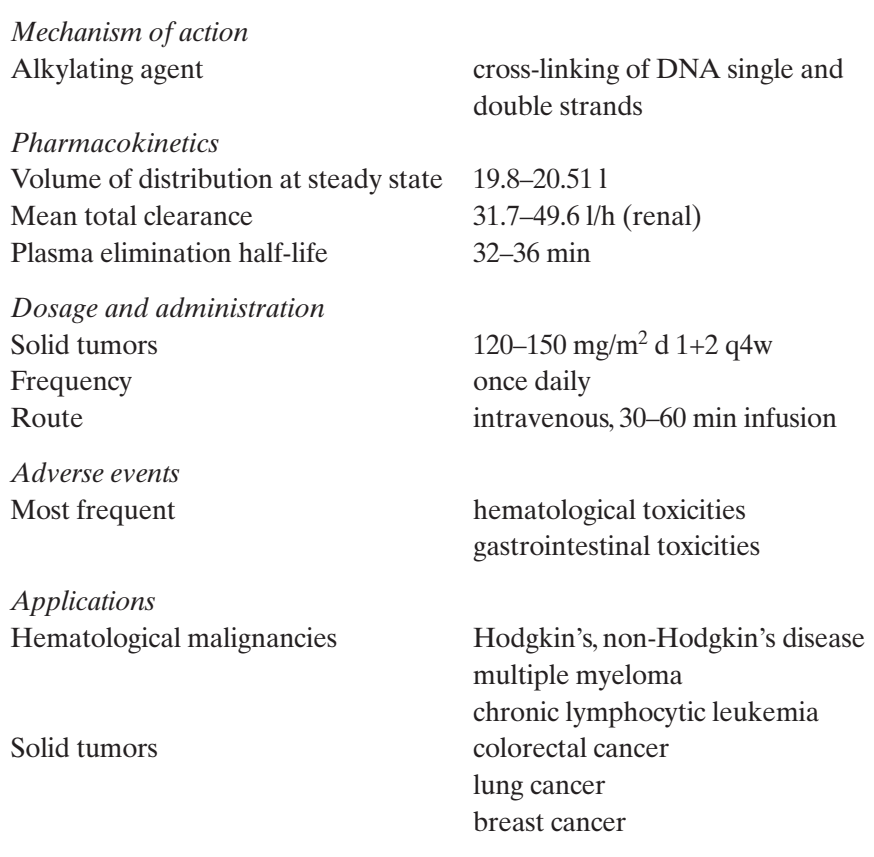

acts as an alkylating agent. Bendamustine undergoes extensive first-pass metabolism, is rapidly metabolized and eliminated, with a half-life of $30 \mathrm{~min}[4,5]$. The properties of bendamustine are summarized in table 1.

Based on the multiple actions and cell cycle effects (such as activation of DNA damage stress response, apoptosis, inhibition of mitotic checkpoints, and induction of mitotic catastrophe) of this agent, mechanism-based combination strategies have been suggested. Early investigations could demonstrate the same efficacy as for other alkylating agents in hematological diseases [6]. Bendamustine as a single agent or in combination with other anticancer agents has also shown pro-apoptotic activity in several in vitro tumor models [7-10]. Unlike other alkylators, bendamustine activates a base excision DNA repair pathway rather than an alkyl transferase DNA repair mechanism [11]. This issue may contribute to its distinct clinical efficacy profile.

In solid tumors, bendamustine has been a promising alternative to other alkylating agents. The most experiences have been gained in therapy of metastatic breast cancer [12,13]. Also in lung and gastrointestinal cancer, bendamustine as monotherapy or in combination with cytotoxic drugs induced remissions [14-18].

Currently, there are few proven treatment options available to patients with breast cancer whose disease has rapidly progressed or is not responding to prior treatment with standard chemotherapies such as anthracyclines and taxanes. Given this high unmet need, it is necessary to investigate new drug application strategies, taking into consideration the individual predisposition to well-known toxicities, such as cardiovascular events and myelosuppression. 
Bendamustine has an excellent toxicity profile, with neutropenia, nausea, and vomiting as most common side effects [19-21]. This aspect is especially important in metastatic patients, as one of the primary aims is to improve quality of life. Therefore, the conclusion was drawn to test bendamustine in patients with solid tumors, preferably breast cancer. In the 1990s, some clinical trials were conducted with bendamustine as primary therapy and as therapy for recurrent breast cancer. Our objective is to review the evidence of bendamustine-containing chemotherapy regimens and bendamustine as monotherapy in MBC patients.

\section{Methods}

The studies analyzed in this report have been identified via systemic computerized search on Medline and the Cochrane Breast Cancer Group Specialized Register back to the 1990s. The codes for 'breast cancer', 'solid tumor' and 'bendamustine' have been used. Details of the search strategy used to create the register are described in the Group's module in The Cochrane Library. The reference lists of other related literature reviews and articles were also searched. Data were collected from published trials and congress abstracts. Studies were assessed for eligibility and quality.

\section{Main Results}

We identified 16 studies, 9 of these ( 6 full publications, $3 \mathrm{ab}-$ stracts only) on breast cancer treatment and 7 studies (4 full publications, 3 abstracts) for other solid tumors. 6 studies were reported as abstracts and provided few details of methodology and complete results. Moreover, information about treatment length and response criteria used was often not completely reported.

\section{Bendamustine as Monotherapy in MBC}

Bendamustine has been evaluated not only in combination with other antitumor drugs, but also as monotherapy in pilot, phase I or phase II trials.

Jamitzky conducted a trial in 18 patients with bendamustine as the third-line therapy. Bendamustine was given at a dosage of $150 \mathrm{mg} / \mathrm{m}^{2}$ on days 1 and 2 of a 3-week cycle for 6 cycles. In 15 evaluable patients, $20 \%$ had a partial remission (PR) and $60 \%$ stable disease (SD). The median progression-free (PFS) and overall survival (OS) was 6 and 8 months, respectively. Hematological adverse events were the main side effects. There were no grade III/IV gastrointestinal toxicities or alopecia [22].

In a multicenter study in recurrent breast cancer (one or more previous regimens for metastatic cancer), the same dosage was used in a 4-week cycle. The overall remission rate was $25 \%$ ( 1 complete response (CR), $8 \mathrm{PR}$ ) with 4 patients having a primary progression. There was no difference between the anthracycline-pretreated and anthracycline-naive patients. The toxicity profile consisted of grade III-IV leukopenia (17\%) and thrombocytopenia grade III-IV (6\%) [23].

Eichbaum conducted a phase II study with weekly bendamustine in MBC patients with 3 or more previous cytotoxic therapies. Most of the patients had received (88\%) anthracyclines and $(71 \%)$ taxanes. Bendamustine $\left(60 \mathrm{mg} / \mathrm{m}^{2}\right)$ was given weekly in 3 consecutive weeks followed by a week of rest as the second-line therapy. In case of Her2/neu overexpression, trastuzumab was given concurrently every week if the patients had not received trastuzumab before (10 of the 34 patients). On average, the patients received 3 cycles (range: $1-6$ ); however, only 10 patients received all planned cycles as scheduled. All patients were eligible for toxicity and 27 for response evaluation. 5 patients $(19 \%)$ reached PR. SD for at least 6 months was reached in 9 patients, resulting in a clinical benefit rate (CBR) of $48 \%$. In a subgroup analysis, CBR increased to $60 \%$ for patients treated with the bendamustine/trastuzumab combination. During the follow-up period of 14 months, disease progressed in all patients and $19(59 \%)$ died. No treatment-related deaths occurred. The median PFS and OS were 6 months (range, 1-16) and 15 months (range, 2-28), respectively. The toxicity profile was moderate with only 2 grade III toxicities as a reversible allergic reaction after the end of the infusion. No grade IV toxicities were observed [24].

A multicenter, open-label, nonrandomized phase II trial has investigated the efficacy and tolerability of single-agent bendamustine in 51 multimodally pretreated patients, with a dose of $120 \mathrm{mg} / \mathrm{m}^{2}$ on days 1 and 2 every 4 weeks [25]. Most patients $(92 \%)$ had received chemotherapy for metastatic disease, $53 \%$ adjuvant chemotherapy, and $47 \%$ an adjuvant hormone therapy. All patients were assessable for toxicity; grade III-IV adverse events occurred very rarely; only 2 febrile neutropenias were observed with no treatment-related deaths. 10 of the 50 patients evaluable for response showed PR (20\%), and 14 patients $(28 \%)$ SD. Primary progression was observed in 26 cases $(52 \%)$. The median time to progression (TTP) was 3.4 months (range, 0.34-51.1); the median duration of response was 6.6 months (range, 1.8-48.7). The response rate was independent of pretreatment.

A summary of the main trials with bendamustine as monotherapy of $\mathrm{MBC}$ is presented in table 2.

\section{Combination Therapy with Bendamustine in $M B C$}

Several pilot, phase I, II and III studies have investigated the efficacy of bendamustine in combination with anthracyclines or other agents in MBC (table 3).

In 2 trials, bendamustine was combined with either adriamycin and a vincristine analogue (VAC scheme) in 62 patients with 
Table 2. Bendamustine as monotherapy: literature overview

\begin{tabular}{|c|c|c|c|c|c|c|}
\hline Reference & Trial & $\begin{array}{l}\text { Patients, } \\
\text { n (overall) }\end{array}$ & Dose, $\mathrm{mg} / \mathrm{m}^{2}$ & $\begin{array}{l}\text { Response rate, } \\
\%\end{array}$ & Toxicity & $\begin{array}{l}\text { Survival, } \\
\text { months (range) }\end{array}$ \\
\hline Jamitzky et al., 1996 [22] & pilot, third-line & 18 & $\begin{array}{l}150 \mathrm{mg} / \mathrm{m}^{2} \text { on day } 1 \\
\text { and } 2 \text { every } 3 \text { weeks }\end{array}$ & $\begin{array}{l}\text { overall 20, } \\
\quad 3 / 15 \text { pts, SD } 60\end{array}$ & $\begin{array}{l}\text { thrombocytopenia, } \\
\text { leukopenia }\end{array}$ & $\begin{array}{l}\text { PFS } 6, \\
\text { OS } 8\end{array}$ \\
\hline Höffken et al., 1998 [23] & multicenter, phase II & 37 & $\begin{array}{l}150 \mathrm{mg} / \mathrm{m}^{2} \text { on day } 1 \\
\text { and } 2 \text { every } 4 \text { weeks }\end{array}$ & $\begin{array}{l}\text { overall } 25, \text { CR } 1 \text { pt, } \\
\text { PR } 8 \text { pts, PD } 4 \text { pts }\end{array}$ & $\begin{array}{l}\text { thrombocytopenia, } \\
\text { leukopenia }\end{array}$ & TTP 2 \\
\hline Eichbaum et al., 2007 [24] & $\begin{array}{l}\text { double-center, open- } \\
\text { label phase II }\end{array}$ & 34 & $\begin{array}{l}\text { Her2 negative: } \\
60 \mathrm{mg} / \mathrm{m}^{2} \text { on day } 1,8, \\
15 \text { every } 4 \text { weeks; } \\
\text { Her2 positive: } \\
60 \mathrm{mg} / \mathrm{m}^{2} \text { on day } 1, \\
8 \text { and } 15 \text { every } \\
4 \text { weeks }+ \text { trastuzu- } \\
\text { mab } 2 \mathrm{mg} / \mathrm{kg} \\
\text { (loading } 4 \mathrm{mg} / \mathrm{kg} \text { ) }\end{array}$ & $\begin{array}{l}\text { overall 48, PR } 19 \\
\text { (5 pts), SD } 33 \\
\text { (8 pts), PD } 48 \\
\text { (13 pts), Her2 } \\
\text { negative: } \\
\text { overall 41, } \\
\text { Her2 positive: } \\
\text { overall } 60\end{array}$ & $\begin{array}{l}\text { infection, } \\
\text { hypotension, } \\
\text { fatigue }\end{array}$ & $\begin{array}{l}\text { PFS } 6(1-16) \text {, } \\
\text { OS } 15(2-28)\end{array}$ \\
\hline Reichmann et al., 2007 [25] & $\begin{array}{c}\text { multicenter, open- } \\
\text { label phase II }\end{array}$ & 51 & $\begin{array}{l}120 \mathrm{mg} / \mathrm{m}^{2} \text { on day } 1 \\
\text { and } 2 \text { every } 4 \text { weeks }\end{array}$ & $\begin{array}{l}\text { overall 48, PR } 20 \\
\quad(10 \text { pts), SD } 28 \\
\text { (14 pts), PD } 52 \\
\text { (26 pts) }\end{array}$ & $\begin{array}{l}\text { nausea, } \\
\text { hematological, } \\
\text { leukopenia, } \\
\text { anemia }\end{array}$ & $\begin{array}{l}\text { ТTР } 3.4 \\
(0.34-51.1)\end{array}$ \\
\hline
\end{tabular}

pts: Patients.

$\mathrm{MBC}$, and/or 5-fluorouracil (5-FU) plus mitomycin C in 40 patients with colorectal cancer. The overall response rate (ORR) was $50 \%$ in breast cancer and $48 \%$ in colorectal cancer, which demonstrated the high efficacy of the drug when bendamustine was added to other cytotoxic agents [26, 27]. The combination of bendamustine with mitoxantrone showed a similar efficacy, with $48 \%$ ORR in advanced breast cancer [28].

A pilot study investigating the efficacy and tolerability of bendamustine $100 \mathrm{mg} / \mathrm{m}^{2}$ in combination with gemcitabine 1000 $\mathrm{mg} / \mathrm{m}^{2}$ was conducted in 14 patients with $\mathrm{MBC}$ and 5 patients with relapsed ovarian cancer. 2 of 9 patients with breast cancer had PR and 4 SD. Because of the severe myelotoxicity, thrombocytopenia, and leukopenia, this study was preterm discontinued [29].

The first randomized trial with 49 patients compared the classical CMF (cyclophosphamide, methotrexate, and fluorouracil) with BMF (bendamustine $30 \mathrm{mg} / \mathrm{m}^{2}$, days 1-8; methotrexate and 5-FU) as first-line therapy in MBC [12]. There was no significant difference between the two groups concerning ORR (46 vs. 52\%). However, there were more complete remissions in the BMF group (16\%) compared to the CMF group (4\%). The median duration of response and the median OS were in favor of BMF, with 17.5 vs. 7 months and 12.9 vs. 5.5 months, respectively.

Because of these promising results, a prospective, randomized, multicenter phase III trial was undertaken to compare two combinations (BMF: bendamustine $120 \mathrm{mg} / \mathrm{m}^{2}$, methotrexate, 5-FU d 1+8 q28; and CMF: cyclophosphamide $500 \mathrm{mg} / \mathrm{m}^{2}$, methotrexate, 5-FU d 1+8 q28) as first-line therapy of 364 patients with $\mathrm{MBC}$ [13]. 175 patients received $\mathrm{BMF}$ and 189
CMF. Visceral metastases were present in $63.8 \%$ of all patients, and $54.4 \%$ had previously received adjuvant chemotherapy. The hematological toxicity was higher in the BMF group (leukopenia 62.7 vs. $40 \%$ ), with comparable nonhematological toxicities. ORR was not different between the two groups with $44 \%$ (BMF) and 40\% (CMF). The response rates at the individual end of study were similar in both treatment arms (BMF: CR 9.3\%, PR 35.2\% and NC (no change) 48.1\%; CMF: CR 7.1\%, PR 32.8\% and NC 55.7\%). Considering only the cases with confirmed responses, the response rates for both treatment arms were again very similar, but lower than expected (BMF: CR 2.5\%, PR 19.8\%; CMF: CR $4.4 \%$, PR $18 \%$ ). However, TTP was significantly longer with BMF compared to CMF (8.2 vs. 6.7 months). Patients who were free from visceral metastases and who had received prior adjuvant therapy showed an improved TTP of 14.6 months for patients on BMF and 4.9 months on CMF. TTP of patients with a confirmed PR (BMF $19.8 \%$ vs. CMF 18\%) tended to be longer in the BMF arm compared to the CMF arm (14.8 vs. 10.3 months).

\section{New Design in MBC: Bendamustine and Taxanes}

There is a paucity of data on the use of bendamustine in combination with taxanes in MBC. In the adjuvant setting, the anthracycline-free combination docetaxel plus cyclophosphamide has shown the same efficacy and a superior toxicity profile to standard anthracycline plus cyclophosphamide, giving the possibility to spare cardiotoxicity [30]. A prospective 
Table 3. Bendamustine in combination with chemotherapeutical agents in breast cancer: literature overview

\begin{tabular}{|c|c|c|c|c|c|c|}
\hline Reference & Trial & $\begin{array}{l}\text { Patients, } \\
\text { n (overall) }\end{array}$ & Dose, $\mathrm{mg} / \mathrm{m}^{2}$ & $\begin{array}{l}\text { Response rate, } \\
\%\end{array}$ & Main toxicities & Survival, \\
\hline Brockmann et al., 1991 [26] & pilot & 62 & $\begin{array}{l}\text { bendamustine } 125 \mathrm{mgm}^{2} \\
\mathrm{~d} 1(-3) \text {, doxorubicin } 20 \\
(40) \mathrm{mg} / \mathrm{m}^{2} \mathrm{~d} 1 \text {, vincris- } \\
\text { tine } 1 \mathrm{mg} / \mathrm{m}^{2} \mathrm{~d} 1, \mathrm{q} 2 \mathrm{w}\end{array}$ & $\begin{array}{l}\text { overall 50, CR 11.3, } \\
\quad \text { PR } 38.7\end{array}$ & $\begin{array}{l}\text { nausea, emesis, } \\
\text { hematological } \\
\text { for high doses, } \\
\text { thrombophlebitis }\end{array}$ & $\begin{array}{l}\text { no data } \\
\text { reported }\end{array}$ \\
\hline Meyer et al., 1998 [29] & pilot & 9 & $\begin{array}{l}\text { bendamustine } 120 \mathrm{mg} / \mathrm{m}^{2} \\
\text { d1+2, gemcitabine } \\
1000 \mathrm{mg} / \mathrm{m}^{2} \mathrm{~d} 1+8 ; \mathrm{q} 4 \mathrm{w}\end{array}$ & PR 22.2, SD 44.4 & $\begin{array}{l}\text { fatigue, } \\
\text { myelotoxicity }\end{array}$ & $\begin{array}{l}\text { study } \\
\text { stopped }\end{array}$ \\
\hline Ruffert et al., 1998 [12] & randomized & 49 & $\begin{array}{l}\text { bendamustine } 30 \mathrm{mg} / \mathrm{m}^{2} \\
\text { d1-8, methotrexate } \\
40 \mathrm{mg} / \mathrm{m}^{2} \mathrm{~d} 1+8,5-\mathrm{FU} \\
500 \mathrm{mg} / \mathrm{m}^{2} \mathrm{~d} 1+8, \mathrm{q} 3 \mathrm{w} \\
(\mathrm{BMF}), \text { versus } \mathrm{CMF}\end{array}$ & $\begin{array}{l}\text { BMF:overall 52, } \\
\text { CR 16, CMF: } \\
\text { overall 49, CR } 4\end{array}$ & $\begin{array}{l}\text { hematological, } \\
\text { no severe } \\
\text { toxicities (liver, } \\
\text { renal) compared } \\
\text { to CMF }\end{array}$ & $\begin{array}{l}\text { TTP } 17.5 \text { vs. } \\
7, \text { OS } 12.9 \\
\text { vs. } 5.5\end{array}$ \\
\hline Schmidt et al., 1999 [28] & $\begin{array}{l}\text { pilot, first- and } \\
\text { second-line, } \\
\text { heterogeneous } \\
\text { collective }\end{array}$ & 39 & $\begin{array}{l}\text { bendamustine } 120 \mathrm{mg} / \mathrm{m}^{2} \\
\mathrm{~d} 1+2 \pm \text { mitoxantrone } \\
8 \mathrm{mg} / \mathrm{m}^{2} \mathrm{~d} 1+2 ; \mathrm{q} 4 \mathrm{w}\end{array}$ & $\begin{array}{l}\text { mono: overall 25, } \\
\text { CR 0, PR 25; } \\
\text { combination: } \\
\text { overall 48, CR 10, } \\
\text { PR38 }\end{array}$ & $\begin{array}{l}\text { hematological, } \\
\text { nausea, emesis }\end{array}$ & $\begin{array}{l}\text { TTP } 440 \text { days } \\
\text { for CR, PR }\end{array}$ \\
\hline $\begin{array}{l}\text { von Minckwitz et al., } 2005 \\
\text { [13] }\end{array}$ & $\begin{array}{l}\text { phase III, rando- } \\
\text { mized, open-label, } \\
\text { multicenter, first-line }\end{array}$ & 345 & $\begin{array}{l}\text { bendamustine } 120 \mathrm{mg} / \mathrm{m}^{2} \\
\text { d1-8, methotrexate } \\
40 \mathrm{mg} / \mathrm{m}^{2} \mathrm{~d} 1+8,5-\mathrm{FU} \\
600 \mathrm{mg} / \mathrm{m}^{2} \mathrm{~d} 1+8, \mathrm{q} 3 \mathrm{w} \\
(\mathrm{BMF}) \text { versus } \mathrm{CMF}\end{array}$ & $\begin{array}{l}\text { BMF: CR 9.3, } \\
\text { PR 35.2, NC 48.1; } \\
\text { CMF: CR 7.1, } \\
\text { PR 32.8, NC 55.7 }\end{array}$ & $\begin{array}{l}\text { hematological, } \\
\text { gastrointestinal, } \\
\text { mucositis, alopecia, } \\
\text { cardiac toxicities } \\
\text { equal distribution }\end{array}$ & $\begin{array}{r}\text { TTP } 14.8 \\
\text { (BMF) } \\
\text { vs. } 10.3 \\
\text { (CMF) } \\
\text { for PR }\end{array}$ \\
\hline
\end{tabular}

pts, Patients.

multicenter phase I dose-finding study with bendamustine and paclitaxel (RiTa trial) in a weekly setting for MBC patients was conducted by the German Breast Group between 2005 and 2007 in order to establish another anthracycline-free feasible combination. The first results of this trial were presented at the German Cancer Congress in February, 2008. Altogether 18 patients with $\mathrm{MBC}$ were enrolled and treated as follows: 3 patients per dose level (maximum 6 patients) and 6 patients at the last dose level, overall 5 levels. The starting dose of bendamustine was $50 \mathrm{mg} / \mathrm{m}^{2}$ and was stepwise increased by $10 \mathrm{mg} / \mathrm{m}^{2}$ up to $70 \mathrm{mg} / \mathrm{m}^{2}$. The starting dose of paclitaxel was $60 \mathrm{mg} / \mathrm{m}^{2}$ and was increased up to $90 \mathrm{mg} / \mathrm{m}^{2}$. No dose-limiting toxicity up to $70 \mathrm{mg} / \mathrm{m}^{2}$ bendamustine and $90 \mathrm{mg} / \mathrm{m}^{2}$ paclitaxel occurred during the first cycle. Dose-limiting toxicities were severe neutropenia and thrombocytopenia as well as nonhematological toxicities $\geq$ National Cancer Institute common toxicity criteria (NCI-CTC) grade 3 (except emesis and alopecia) in the first cycle. The combination of bendamustine with paclitaxel seems to be effective with $1 \mathrm{CR}$ and $3 \mathrm{PR}$, and to have a good tolerability with only 5 serious adverse events (2 fatigues, 1 anemia, 1 allergic reaction and 1 dehydration). Therefore, a phase II trial is now being conducted to investigate the efficacy and tolerability of the determined doses of bendamustine $70 \mathrm{mg} / \mathrm{m}^{2}$ in combination with paclitaxel
$90 \mathrm{mg} / \mathrm{m}^{2}$ [31]. The weekly setting of paclitaxel plus bendamustine might be an even more efficacious and tolerable anthracycline-free combination and is therefore worth to be further explored.

\section{Activity of Bendamustine on Central Nervous System Breast Cancer Metastases}

Central nervous system (CNS) metastases are present in $10 \%$ of $\mathrm{MBC}$ and have the worst prognosis of all metastatic sites of breast cancer, despite palliative treatment with radiotherapy. The blood-brain barrier represents a major problem for most drugs because of poor permeability. Nevertheless, bendamustine may be active in CNS metastases, as described by Zukols$\mathrm{ki}$ in a first case report [32]. A young patient with hormone receptor-negative $\mathrm{MBC}$ and advanced liver, bone and CNS metastases showed a promising benefit after 2 courses of bendamustine, with regression of liver metastases and a complete disappearance of 2 of 3 CNS lesions. Moreover, the patient's performance status improved considerably. This finding may suggest an alternative therapeutic option with bendamustine against CNS metastases of breast cancer and needs to be further investigated. 


\section{Conclusions}

Bendamustine is a substance that has been used for more than 40 years in indications like non-Hodgkin's lymphoma, chronic lymphocytic leukemia, multiple myeloma, Hodgkin's disease, small cell lung cancer, colorectal cancer and breast cancer. The therapy decision for MBC should take into consideration the patient's expectation, health condition and age, aggressiveness of disease, location of metastasis, and previous treatments. The combination of bendamustine with methotrexate and fluorouracil is recommended in individual situations by the Commission Mamma of the Arbeitsgemeinschaft Gynäkologische Onkologie e.V. (AGO) as an alternative to polychemotherapies, such as the combination of anthracyclines, taxanes and capecitabine, with a level of evidence (LOE) $1 \mathrm{~b}$ (AGO +/-) [33, 34].

The particular importance of bendamustine as a single agent is clearly proven, as it is mostly used as monotherapy, mainly in a palliative setting, in breast cancer. The advantage compared with other comparable drugs is attributed to the fact that ben- damustine causes hardly any alopecia or organ toxicity, resulting in a profit for the patients in terms of quality of life. Moreover, patients with cardiac co-morbidity can benefit from bendamustine as an alternative to vinorelbine and capecitabine therapy.

The main toxicity caused by bendamustine is hematotoxicity, defined as leukopenia, neutropenia and thrombocytopenia. In terms of non-hematologic toxicity, nausea and vomiting are dominant. Toxicity is generally mild, manageable and controllable. Late effects are unknown so far. Secondary malignancies are not documented as late effects, but this might be due to the relatively short follow-up periods and small patient collectives in the recently performed systematic studies.

The standard treatment in MBC has been modified due to the introduction of new drugs like the taxanes; thus, the role of bendamustine would have to be redefined and tested against modern therapy schedules. Paclitaxel plus bendamustine in a weekly setting might be an even more efficacious and tolerable anthracycline-free combination and is therefore worth to be further explored.

\section{References}

1 Brustkrebs: Gesundheitsberichterstattung des Bun- 10 Chow KU, Nowak D, Boehrer S, Ruthardt M, Knau des - Robert Koch Institut; Heft 25: www.rki.de.

$>_{2}$ Giordano S, Buzdar A, Smith T, Kau SW, Yang Y, Hortobabgy G: Is breast cancer survival improving? Trends in survival for patients with recurrent breast cancer diagnosed from 1974 through 2000 Cancer 2004;100:44-52.

>3 Ozegowski W, Krebs D: IMET 3393, -[1-Methyl5-bis-( $\beta$-chloräthyl)-amino-benzimidazolyl-(2)]buttersäurehydrochlorid, ein neues Zytostatikum aus der Reihe der Benzimidazol-Loste. Zbl Pharm 1971;110:1013-1019.

4 Matthias M, Preiss R, Sohr R, Possinger K: Pharmacokinetics of bendamustine in patients with malignant tumors. Proc Am Soc Clin Oncol 1995; 14: abstr 1476

5 Matthias M, Preiss R, Sohr R, Possinger K: Pharmacokinetics of bendamustine in tumor patients Onkologie 1994;17(suppl 2):94.

6 Anger G, Fink R, Fleischer J, Hesse P, Krug K, Raderecht C, Rieche K, Subert L, Wutke K: Vergleichsuntersuchungen zwischen Cytostasan und Cyclophosphamid bei der chronischen Lymphadenose, dem Plasmozytom, der Lymphogranulomatose und dem Bronchialkarzinom. Dtsch Gesundheitswesen 1975;30:1280-1285.

7 Nowak D, Boehrer S, Brieger A, Kim SZ, Schaaf S, Hoelzer D, Mitrou PS, Weidmann E, Chow KU: Upon drug-induced apoptosis in lymphoma cells Xlinked inhibitor of apoptosis (XIAP) translocates from the cytosol to the nucleus. Leuk Lymphoma 2004;45:1429-1436.

8 Konstantinov SM, Kostovski A, Topashka-Ancheva M, Genova M, Berger MR: Cytotoxic efficacy of bendamustine in human leukemia and breast cancer cell lines. J Cancer Res Clin Oncol 2002;128: 271-278.

-9 Schwanen C, Hecker T, Hubinger G, Huebinger G, Wölfle M, Rittgen W, Bergmann L, Karakas T: In vitro evaluation of bendamustine induced apoptosis in B-chronic lymphocytic leukemia. Leukemia 2002;16:2096-2105.
A, Hoelzer D, Mitrou PS, Weidmann E: Synergistic effects of chemotherapeutic drugs in lymphoma cells are associated with down-regulation of inhibitor of apoptosis proteins (IAPs), prostate-apoptosis-response-gene 4 (Par-4), death-associated protein (Daxx) and with enforced caspase activation. Biochem Pharmacol 2003;66:711-724.

11 Leoni LM, Bailey B, Reifert J, Bendall H, Zeller RW, Corbeil J, Elliot G, Niemeyer C: Bendamustine displays a distinct pattern of cytotoxicity and unique mechanistic features compared with other alkylating agents. Clin Cancer Res 2008;14:309-317.

12 Ruffert K: Primäre Chemotherapie des metastasierten Mammakarzinoms mit Bendamustine-hydrochlorid, Methotrexat und Flourouracil versus Cyclophosphamid, Methotrexat und Flourouracil.

13 von Minckwitz G, Chernozemsky I, Sirakova L, Chilingirov P, Souchon R, Marschner N, Kleeberg U, Teskov C, Fritze D, Thomssen C, Stuart N, Vermorken JB, Loibl S, Merkle KH, Kaufmann M: Bendamustine prolongs progression-free survival in metastatic breast cancer (MBC): a phase III prospective, randomized, multicenter trial of bendamustine hydrochloride, methotrexate and 5-FU (BMF) versus CMF as first-line treatment of MBC. Anti-Cancer Drugs 2005;16:871-877.

14 Reck M, Haering B, Koschel G, Kaukel E, von Pawel L, Gatzemeier U: Chemotherapie des fortgeschrittenen kleinzelligen und nicht-kleinzelligen Bronchialkarzinoms mit Bendamustine. Eine Phase-II-Studie. Pneumologie 1997;51:abstr 260. Pawel L, Gatzemeier U: Chemotherapy of advanced SCLC and NSCLC with bendamustine - A phase II-study. J Cancer Res Clin Oncol 1998;124 (suppl):R109. Zentralbl Chir 1998;123:156-158.

15 Haering B, Reck M, Koschel G, Kaukel E, von
16 Ridwelski K, Rudolph S, Fahlke J, Gebauer T, Lippert H: A new combination chemotherapy with bendamustine (B), mitomycin (M), 5-FU (FU) and prednisolon $(\mathrm{P})$ in advanced gastrointestinal tumours with progress under standard chemotherapy J Cancer Res Clin Oncol 1998;124(suppl):R158.

17 Schöffski P, Hagedorn T, Grünwald V, Paul H, Merkle KH, Kowalski R, Ganser A: Repeated administration of short infusions of bendamustine: a phase I study in patients with advanced progressive solid tumors. J Cancer Res Clin Oncol 2000;126: 41-47.

18 Schöffski P, Seeland G, Engel H, Grünwald V, Paul H, Merkle KH, Kowalski R, Ganser A: Weekly administration of bendamustine: A phase I study in patients with advanced progressive solid tumors. Ann Oncol 2000;11:729-734.

19 Pönisch W, Mitrou PS, Merkle K, Herold M, Assmann M, Wilhelm G, Dachselt K, Richter P, Schirmer V, Schulze A, Subert R, Harksel B, Grobe N, Stelzer E, Schulze M, Bittrich A, Freund M, Pasold R, Friedrich T, Helbig W, Niederwieser D; East German Study Group of Hematology and Oncology (OSHO): Treatment of bendamustine and prednisone in patients with newly diagnosed multiple myeloma results in superior complete response rate, prolonged time to treatment failure and improved quality of life compared to treatment with melphalan and prednisone - a randomized phase III study of the East German Study Group of Hematology and Oncology (OSHO). J Cancer Res Clin Oncol 2006;132:205-212.

20 Preiss J, Heck HK, Schmidt P: Bendamustine in the therapy of low-grade malignant lymphomas (abstract). Eur J Cancer 1999;35(suppl 4):336.

21 Herold M, Keinert K, Anger G: Risk-adapted combined radiotherapy and chemotherapy for Hodgkin's disease - results of a pilot study. Onkologie 1992;15:502-505. 
22 Jamitzky T, Lange OF: Third-line chemotherapy with bendamustine for metastatic breast cancer. A prospective pilot study. 7th EORTC Breast Cancer Working Conference. Abstract PP-7-14. Eur J Cancer 1996;32A(suppl 2):47.

23 Höffken K, Merkle KH, Schönfelder M, Anger G, Brandtner M, Ridwelski K, Seeber S: Bendamustine as salvage treatment in patients with advanced progressive breast cancer: a phase II-study. J Cancer Res Clin Oncol 1998;124:627-632.

24 Eichbaum MH, Schuetz F, Khbeis T, Lauschner I, Foerster F, Sohn C, Schneeweiss A: Weekly administration of bendamustine as salvage therapy in metastatic breast cancer: final results of a phase II study. Anticancer Drugs 2007;18:963-968.

25 Reichmann U, Bokemeyer C, Wallwiener D, Bamberg M, Huober J: Salvage chemotherapy for metastatic breast cancer: results of a phase II study with bendamustine. Ann Oncol 2007;18:1981-1984.

26 Brockmann B, Geschke E, Schmidt UM, Ebeling K: Therapieergebnisse und toxische Nebenwirkungen der Kombination Cytostasan, Adriamycin und Vincristin als 'second-line'-Therapie beim metastasierten Mammakarzinom. Geburtshilfe Frauenheilkd 1991;51:383-386.
27 Ruffert K: Die Therapie des rezidivierenden kolorektalen Karzinoms mit 5-Fluorouracil/Mitomycin/Bendamustine/Prednison. 22. Deutscher Krebskongress Berlin 1996;abstr P2.03.05.

28 Schmidt P, Heck HK, Preiss J: Bendamustine/ mitoxantrone in the treatment of advanced breast cancer. ECCO 1999;10:324.

29 Meyer A, Grischke E, Wallwiener D, Bastert G: Response and toxicity of chemotherapy with gemcitabine and bendamustine in advanced ovarian cancer and breast cancer. J Cancer Res Clin Oncol 1998:124:R123 (abstr P1-09,28).

30 Jones SE, Savin MA, Holmes FA, et al.: Phase III trial comparing doxorubicin plus cyclophosphamide with docetaxel plus cyclophosphamide as adjuvant therapy for operable breast cancer. J Clin Oncol 2006;24:5381-5387.

31 Loibl S, Murmann C, Schwedler K, Warm M, Müller L, Heinrich G, Nekljudova V, von Minckwitz G: A multicentre phase I dose finding study to investigate the combination of bendamustine with weekly paclitaxel as first or second line therapy in patients with anthracycline pretreated metastatic breast cancer - the RiTa trial. DKG 2008;abstr.
32 Zulkowski K, Kath R, Semrau R, Merkle K, Höffken K: Regression of brain metastases from breast carcinoma after chemotherapy with bendamustine. J Cancer Res Clin Oncol 2002;128:111-113.

33 Arbeitsgemeinschaft Gynäkologische Onkologie e.V.: AGO Breast Guidelines 2008. www.ago-online.org/index.php?lang=de\&site=mamma_guide_0 8_1_1\&topic=mamma_guide.

34 Jackisch C, Untch M, Chatsiproios D, Lamparter C, Overkamp F, et al.: German Recommendations for Diagnosis and Treatment of Breast Cancer 2008. Adherence to Treatment Guidelines in Breast Cancer Care - a Retrospective Analysis of the 'Organgruppe Mamma der Arbeitsgemeinschaft Gynaekologische Onkologie'. Breast Care 2008;3: 87-92. 